SOCIETY OF

ARCHITECTURAL

HISTORIANS

\title{
Review
}

Reviewed Work(s): İstanbul 1910-2010 Kent, Yapılı Çevre ve Mimarlık Kültürü Sergisi City, Built Environment and Architectural Culture Exhibition by Review by: Lucienne Thys-Şenocak

Source: Journal of the Society of Architectural Historians, Vol. 70, No. 3 (September 2011), pp. 379-381

Published by: University of California Press on behalf of the Society of Architectural Historians

Stable URL: http://www.jstor.org/stable/10.1525/jsah.2011.70.3.379

Accessed: 31-05-2017 06:12 UTC

JSTOR is a not-for-profit service that helps scholars, researchers, and students discover, use, and build upon a wide range of content in a trusted digital archive. We use information technology and tools to increase productivity and facilitate new forms of scholarship. For more information about JSTOR, please contact support@jstor.org.

Your use of the JSTOR archive indicates your acceptance of the Terms \& Conditions of Use, available at http://about.jstor.org/terms

Society of Architectural Historians, University of California Press are collaborating with JSTOR to digitize, preserve and extend access to Journal of the Society of Architectural Historians 
of Architecture, organized a show that looks at an entirely different aspect of Stirling's career and ultimately his impact on the profession: his teaching. Stirling was an instructor at Yale for twenty-four years and served as the inaugural Davenport Visiting Professor for seventeen of them. Seventysix of Stirling's nearly two hundred students are represented in the show, which begins with the first studio in 1959 and ends with the final semester in 1983 .

Unlike Vidler's hands-off approach, An Architect's Legacy; James Stirling's Students at Yale, 1959-83 exhibits tight curatorial control. A 24-inch ribbon snakes through and around gallery space, changing color to mark the five different sections. The ribbon is an organizational device, a figural piece, and a conceptual commentary on Stirling's architecture and what Petit found to be its dominant feature-the role of circulation. When the ribbon breaks from the wall or floor and becomes a hanging element, it displays student drawings on one side, and a project simultaneously underway in Stirling's office on the other-a device that, while designed to allow viewers to make connections to Stirling's work, is in fact difficult to navigate. In and around the ribbon, vitrines display original drawings.

The first section, "Articulated Functionalism," features studios from 1959 to 1964, whose graphic language of hardline axonometrics is resonant with Stirling's contemporaneous Leicester building. The next, "The New City," 1965-69, might more accurately be described as the Craig Hodgetts section, as it is dominated by his neon-rendered images and the only models on display. The show continues around the gallery perimeter with "Urban Insertions," 1970-75, and “Architectural Agglomerates" 1976-77. The final section, "Fragmented Monumentality," 1978-83, is the largest, and here the ribbon peels off of the edge to occupy most of the central space of the gallery. Whether intended or not, the show emphasizes the later postmodern work, if only through the volume of material.

An architectural exhibit on student work raises a series of questions about its value and interest, regardless of the instructor. There is the inevitable question of quality - the best students are not necessarily the ones who submit their material-and the drawings are, perhaps inevitably, uneven. Petit's open call to all of Stirling's former students is clearly (and admittedly) born of the archival impulse of Robert A. M. Stern, dean of the Yale School of Architecture, but what does it offer the viewer?

Upon the first publication of Stirling's collected works, in 1975, Rafael Moneo wrote that the book was not so much a review of Stirling's work as a history of modern architecture over the previous twenty-five years. ${ }^{3}$ We could extend that argument to this show as well; these student drawings serve not so much as a documentation of the evolution of Stirling's architectural language as of architectural culture more broadly, from the late fifties through the early eighties.

Both exhibitions reflect as well as fuel the recent tsunami of interest in Stirling's architecture. But why Stirling now? In his exhibition talk Vidler argued that young architects and scholars were discovering Stirling again after a too-long hiatus. Certainly this can be attributed, at least partly, to the fact that enough time has passed to consider Stirling as history. But there is a more fundamental reason, I would argue, for our willingness to unearth this work again, and, more importantly, to accept someone who has for years been an unpopular if not forgotten figure. We are seeing more of Stirling these days for the simple reason that postmodernism-with which Stirling is inevitably affiliated-has recently come out of historical hiding to emerge as not only an acceptable but a fertile area of architectural inquiry. The irony in this resurgence would not have escaped Stirling, who refused the term postmodernism and any affiliation with it.

Claire Zimmerman recently suggested that Stirling's astounding absence from architectural historiography is a result of architectural culture's deepseated fear that his postmodernist operations are, in fact, still at work. ${ }^{4}$ Perhaps, then, this turn to Stirling suggests that we are ready to embrace his reuse and reinvention of architecture's history and traditions as a productive and ongoing response to modernism. Both exhibitions contribute to the process of seeing Stirling's work again-through a closer look into his extensive archive and an assessment of his long teaching careerrevisioning our simplistic notion of the modern/postmodern in his work and, ultimately, in architectural culture more broadly.

\section{AMANDA REESER LAWRENCE}

Northeastern University

\section{Related Publication}

Anthony Vidler, James Frazer Stirling: Notes from the Archive. New Haven: Yale University Press, 2010, 300 pp., 360 color illus. \$70 (cloth), ISBN 0300167237

\section{Notes}

1. The reviewer saw the exhibition at Yale.

2. Anthony Vidler, preface, James Frazer Stirling: Notes from the Archive (New Haven and London: Yale University Press, 2010), 17.

3. Rafael Moneo, Review of James Stirling: Buildings and Projects in Oppositions 7 (Winter 1976), 90.

4. Claire Zimmerman, "James Stirling Reassembled,” AA Files 56 (Nov. 2007), 30-41.

\section{İstanbul 1910-2010 Kent, Yapılı Çevre ve Mimarlık Kültürü Sergisi City, Built Environment and Architectural Culture Exhibition}

Santralistanbul, Bilgi University, Istanbul 15 September 2010-16 January 2011

Istanbul 1910-2010: City, Built Environment and Architectural Culture was one of many cultural events held during the celebration of the city as the 2010 European Capital of Culture. Stretching over 75,000 square feet of exhibition space, accompanied by explanatory texts in English and Turkish, and split among four floors of the gallery at Santralistanbul, Bilgi University's Center for Arts and Culture, the exhibit was as complex and overwhelming as its subject, Istanbul. The intention of the exhibit was to chart the spatial and social transformations of the city through four phases of its recent past, from its final days as the capital of 
the Ottoman Empire to its present state as a mega-city of over 14 million residents. The four main curators, from Bilgi University-Günkut Akın, Sibel Bozdoğan, İhsan Bilgin, and Tansel Korkmazdivided Istanbul's last century into four chronological slices and staged four quite separate exhibits: "The Waning of the Empire (1910-1930);" "The Republican Intervention (1930-1950);" "The Great Implosion (1950-1983)," and "Between the Local and the Global (1983-2010)" (Figure 1). While the lack of a clear curatorial meta-narrative and some unfortunate design flaws in both the exhibition and the catalog made it a challenge to navigate the exhibition, the formidable amount of research that went into its production, and the myriad archival photographs, plans, and drawings-many exhibited for the first time-made it well worth the effort.

The most popular section of the exhibition, "The Waning of the Empire," was located on the fourth floor of Santralistanbul. Curated by Günkut Akın, this floor was organized in a traditional chronological framework and touched upon cultural themes and events that had occurred as the city underwent the transition from being the administrative and financial hub of the Ottoman empire, through its occupation following World War I (1918-23) when "the city acquired its most cosmopolitan appearance," to the abandonment of the historic peninsula by the political elite. The emergence of new types of structures, such as cinemas, photography studios, hotels, multi- story apartments, and office buildings, many designed by Vedat Tek and Mimar Kemalettin in the First National Style, were introduced on this floor and made more vivid by a three-dimensional model of the city. While a prodigious number of archival photographs from many private and state collections in Turkey and abroad had the potential to turn this section into yet another nostalgic portrait of Istanbul, the curator pushed beyond the standard tropes of Orientalism and highlighted the city's complex hybridity, cosmopolitanism, and the very dynamic life that Istanbul and its residents experienced during these "waning" decades of empire.

Introducing "Waning of the Empire" were photographic reproductions of the mammoth Silahtarağa Power Plant, which supplied electricity to Istanbul from 1914 to 1983 ; since its renovation in 2004 this imposing structure and its adjoining purpose-built gallery have housed exhibitions. There were many opportunities to detour from the central narrative to explore chapters of the city's history, such as the New Hellenism movement (Nev Yunanlik) of the Istanbul literati, which included Sedad Hakkı Eldem's Mediterranean sketches of 1928-29, along with caricatures of and poems by Yahya Kemal, the late Ottoman poet who launched a cultural movement that celebrated the literature of the ancient Mediterranean basin. Osman Hamdi Bey, the famed Ottoman painter and founder of Istanbul's Archaeological Museum, also made an appearance here,

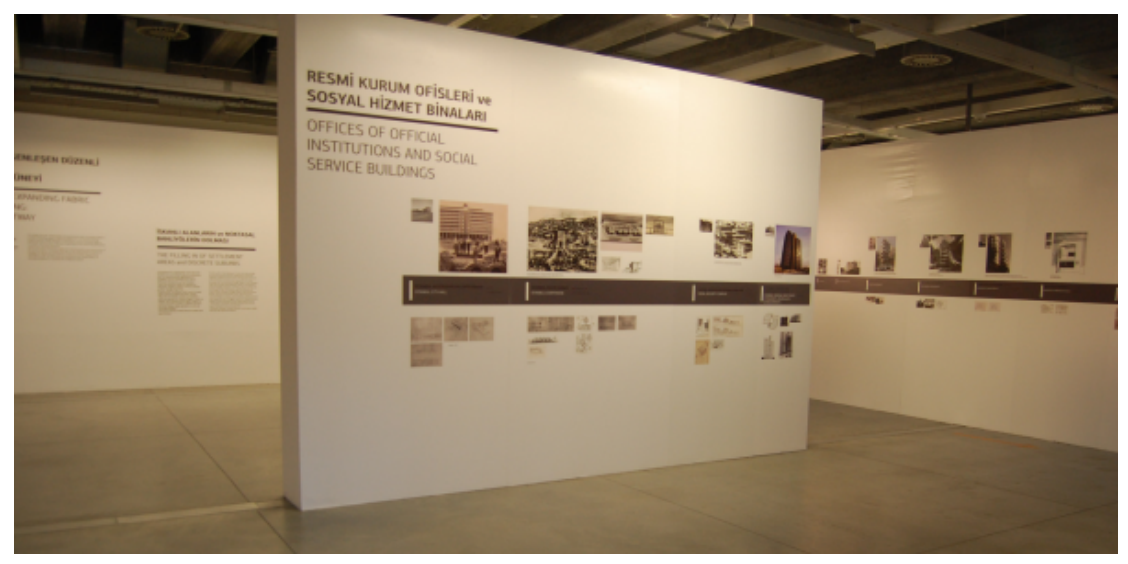

Figure 1 General view of third-floor panels, Istanbul 1910-2010 (photo: author)

dressed in the exotic costumes of the Orient, along with other "cultural transvestites" and denizens of the city, such as Pierre Loti, the Japanese shopkeeper Yamada Torajiro, and Le Corbusier, the latter posing as a harem odalisque. Pictures of the bamboo stalks planted by Osman Hamid Bey at the turn of the century, and growing today in the garden outside the Istanbul Archaeological Museum, attest to the porosity that still defines the concepts of East and West for Istanbul residents.

Pre-World War I newspaper articles from the Şebbal Magazine about real and envisioned Ottoman zeppelins and futuristic biomorphic flying machines, including photos of the 1919 launch of a huge "Freedom Balloon" from Istanbul's Talimhane, all challenged the traditional interpretation of an empire whose decline was due to lack of Ottoman curiosity about new technology. Rather than "collective amnesia," the term which İhsan Bilgin used in the preface to the unpaginated catalog to describe the mentality of Istanbul's residents in the past hundred years, this floor revealed a city strongly rooted in the Ottoman traditions of the nineteenth century, many which flourished until the 1920s.

It was only after 1930, and on the third floor of the exhibition, where two of the exhibition's time slices, 1930-50 and 195083 , were presented, that Istanbul began to make a clear break from its Ottoman past. "The Republican Intervention: 1930 1950," curated by Sibel Bozdoğan, explored the modernizing agendas of newly born Turkish nationalism and how these reshaped the fabric of the city and the lives of its citizens. Much of the texture of Istanbul was altered by heavy-handed urban renewal projects and master plans, several of which required parks, promenades, squares and other espaces libres to qualify as modern. Much of this was the work of Henri Prost, the French urban planner who was consultant to Istanbul's municipality between 1936 and 1951. Present plans for a Levent-Maslak metro line and the use of Yenikap1 as a maritime transit point had been envisioned already more than seventy years ago. Using reproductions of newspaper articles, architectural 
plans, archival photographs and films, this floor of the exhibition demonstrated how Istanbul became "modern" with the arrival of motor traffic (in the form of private and state sponsored buses) and the creation of novel structures and spaces for the work and play of Turkey's new citizens. It was in this era that factories, beaches, swimming pools, sports halls, and "gazinos" (music halls) appeared on Istanbul's cityscape. Many of the structures associated with this important chapter in the industrial heritage of the city, such as the Municipal Bus Terminal in Sisli of 1947, have been destroyed. Punctuating the exit panels on this floor were lists of the old Ottoman street names and their new Republican appellations in the Greek, Jewish, and Armenian quarters of the city, a poignant reminder of the tumultuous demographic and political changes that accompanied urban planning.

The later phases of modernization were also dealt with on this floor in "Urban Implosion 1950-1983," curated by İhsan Bilgin. Bilgin attributed much of the change in Istanbul's urban landscape during this thirty-year period to the government's changing economic policies, including import substitution, amnesties for illegal squatter housing, and incentives for new patterns of capitalist-driven consumption. The first Bosphorus bridge, shopping malls, and a new type of commercial space on the ground floor of apartment buildings made their debuts in these years, the last competing with the local corner grocery stores that had been the commercial mainstay of the city's neighborhoods in previous decades. Certainly the highlight of this part of the exhibition was an huge model of Istanbul between World War I and World War II, built at a scale of 1:1250 and filling an entire room (Figure 2). The model was based on data

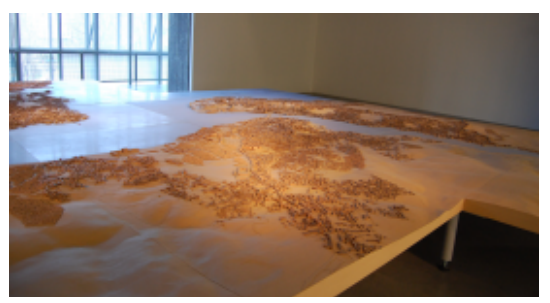

Figure 2 Model of Istanbul between the world wars (photo: author) compiled from several historical maps of the city, including the colorful insurance maps created by Jacques Pervititch between 1922 and 1945, and was testimony to the painstaking diligence of the students and faculty who participated in the creation of Istanbul 1910-2010.

On the second floor, in "The Pressure of the Global, 1983-2010," curated by Tansel Korkmaz, the disjunction between the very different visions of the Istanbul Chamber of Architects and the Istanbul Municipality regarding the city's past, present, and future was quite pronounced. Both texts and images castigated the mass housing and urban regeneration projects undertaken by the Istanbul municipality in the past three decades. A long list of court cases-won, lost, and continuingbetween the Chamber of Architects, the municipality, and other "investors" in the city highlighted the struggle for power among the stakeholders who sought to shape the social, cultural, economic, and spatial character of the city. As Istanbul is still under the threat of being removed from the World Heritage List and being designated as an endangered site, it is clear that the curators, most whom are active members in the Chamber of Architects, have a point. But on this floor the curator needlessly risked alienating some percentage of the audience by calling the new exclusive suburban communities "Narcissus' paradise," where "The new rich are escaping from a city polluted in all respects to flee to false paradises and lock themselves in gated compounds." In the same vein, the curatorial voice in this final section disparaged the central government's Mass Housing Development Administration (TOKI) and the low-income highrise apartment complexes in which many of the urban poor now reside. These structures were classified under the caption "Sediments" (Tortular) and labeled simply as "non-places of alienation."

If Istanbul 1910-2010 is to become the seed of a future city museum, as is currently proposed, it must try to speak more cohesively, inclusively, and perhaps less architecturally, to the diverse people who inhabit and visit the city and turn to this exhibition to help make sense of it. In designing the exhibition, the opportunity to create a more participatory space within the vast Santralistanbul was lost when the entrance floor was turned into a cavernous display of oversized and largely unreadable digital maps. Excessively long wall texts and undersized images in both the exhibit and the catalog did little to enhance the viewing experience. But Istanbul 19102010 's curators and contributors have been working tirelessly to ensure that their vision for the city prevails. Like the Istanbul Chamber of Architects, which we are told in one of the panels, has "been so alone in its stand against extremely strong centers of power that it was condemned to take an instinctively heroic position," Istanbul 1910-2010 City, Built Environment and Architectural Culture is another battle in the ongoing war over the fate of this city.

$$
\text { LUCIENNE THYS-ŞENOCAK }
$$$$
\text { Koç University, Istanbul }
$$

\section{Related Publication}

İhsan Bilgin, Günkut Akın, Burak Boysan, Sibel Bozdoğan, Murat Güvenç, Tansel Korkmaz, Eda Ünlü Yücesoy. Istanbul 1910-2010: City, Built, Environment and Architectural Culture Exhibition. Istanbul: Bilgi İletişim Yayıncılık, 2010, unpaginated, \$160, ISBN 9786053991663 TL95

\section{Auf den zweiten Blick. Architektur der Nachkriegszeit in Nordrhein- Westfalen / A Second Look: Postwar Architecture in North Rhine- Westphalia}

Dortmunder U, Dortmund, Germany

9 September-9 November 2010

"Not a few historic monuments lead an inconspicuous life," according to Hans H. Hanke. ${ }^{1}$ That is especially the case for most of buildings associated with the reconstruction of West Germany after 1945. What was built immediately and in deprived conditions for the surviving inhabitants of its war-torn urban centers-plus nearly ten million refugees-is still on view in the housing estates of the country's large cities, and it exhibits the strange charm of casual insignificance. Only with the founding of the Federal 